\title{
Formulasi Handbody Lotion (Setil Alkohol dan Karagenan) dengan Penambahan Ekstrak Delima Merah
}

\author{
Formulation of Handbody Lotion (Cetyl Alcohol and Carrageenan) with Addition of Red Pomegranate Extract
}

\author{
Nunung Nurhaijah Hudairiah' ${ }^{\star}$, S. Rosalinda1 ${ }^{1}$, Asri Widyasanti ${ }^{1}$
}

${ }^{1}$ Teknik Pertanian dan Biosistem, FTIP, Universitas Padjadjaran

Jl. Raya Bandung-Sumedang KM. 21 Jatinangor, Kabupaten Sumedang 45363

*E-mail: nunung17001@mail.unpad.ac.id

Diterima: 10 Februari 2021; Disetujui: 6 Juli 2021

\begin{abstract}
ABSTRAK
Delima merah mengandung antioksidan vitamin $\mathrm{C}$ yang berfungsi untuk mencegah oksidasi, penuaan, dan regenerasi sel. Ekstrak delima merah dapat dimanfaatkan sebagai bahan alami dalam handbody lotion. Handbody lotion merupakan kosmetik yang mengandung banyak air berbentuk emulsi tipe minyak dalam air yang diaplikasikan pada kulit bagian tangan dan tubuh. Salah satu bahan penyusun handbody lotion adalah setil alkohol yang berfungsi sebagai pengemulsi, pengental, dan penstabil yang dapat digantikan oleh karagenan. Penelitian ini bertujuan untuk menentukan konsentrasi terbaik dari setil alkohol dan karagenan serta penambahan ekstrak delima merah pada handbody lotion. Metode penelitian yang digunakan adalah metode eksperimental laboratorium dengan analisis statistik One-Way ANOVA dan uji lanjutan Duncan serta analisis data secara deskriptif. Tahapan penelitian terdiri dari pembuatan handbody lotion menggunakan setil alkohol $(0,5 \%$; $0,7 \%$; $1,0 \%$ ) dan karagenan (1,0\%; 2,0\%; 3,0\%) serta penambahan ekstrak delima merah sebesar $0,2 \%$ dan $2,5 \%$ pada handbody lotion terbaik yang didapatkan. Hasil penelitian menunjukkan bahwa handbody lotion memenuhi SNI 16-4399-1996 (penampakan, $\mathrm{pH}$, viskositas) dimana handbody lotion terbaik dibuat menggunakan setil alkohol 1,0\% (rendemen 92,8\%; homogen; $\mathrm{pH}$ 8,0; viskositas 4950,0 cP) dan karagenan 3,0\% (rendemen 92,5\%; homogen; pH 8,0; viskositas 9262,5 cP). Handbody lotion dengan setil alkohol 1,0\% dan ekstrak delima merah 0,2\% memiliki rendemen 92,5\%; homogen; $\mathrm{pH} 7,0$; dan viskositas 4550,0 cP. Handbody lotion dengan karagenan 3,0\% dan ekstrak delima merah $2,5 \%$ memiliki rendemen 92,5\%; homogen; $\mathrm{pH} 7,0$; dan viskositas 5233,3 cP. Penambahan ekstrak delima merah menghasilkan handbody lotion yang memenuhi SNI 16-4399-1996.
\end{abstract}

Kata kunci: delima merah; handbody lotion; karagenan; setil alkohol; vitamin c

\section{ABSTRACT}

Red pomegranate contains antioxidant vitamin $C$ which functions to prevent oxidation, aging, and cell regeneration. Red pomegranate extract can be used as natural ingredient in handbody lotion. Handbody lotion is cosmetics that contains a lot of water in the form of oil-in-water emulsion that is applied to skin of hands and body. One of ingredients for handbody lotion is cetyl alcohol which functions as an emulsifier, thickener, and stabilizer which can be replaced by carrageenan. This study aims to determine the best concentration of cetyl alcohol and carrageenan and red pomegranate extract addition to handbody lotion. The research method used was laboratory experimental method with One-Way ANOVA statistical analysis and Duncan's post-hoc test and descriptive data analysis. The research stages consisted of making handbody lotion using cetyl alcohol (0,5\%;0,7\%; 1,0\%) and carrageenan (1,0\%; 2,0\%; 3,0\%) and red pomegranate extract addition of $0,2 \%$ and $2,5 \%$ in the best handbody lotion. The results showed that handbody lotion met SNI 16-4399-1996 (appearance, pH, viscosity) where the best handbody lotion was made using cetyl alcohol 1,0\% (yield 92,8\%; homogeneous; $\mathrm{pH} 8,0 ;$ viscosity $3950,0 \mathrm{cP}$ ) and 3,0\% carrageenan (yield 92,5\%; homogeneous; $\mathrm{pH} 8,0$; viscosity 9262,5 $\mathrm{cP}$ ). Handbody lotion with 1,0\% cetyl alcohol and 0,2\% red pomegranate extract had yield of 92,5\%; homogeneous; $\mathrm{pH} 7,0$; and viscosity of $4550,0 \mathrm{cP}$. Handbody lotion with 3,0\% carrageenan and 2,5\% red pomegranate extract had yield of 92,5\%; homogeneous; $\mathrm{pH} 7,0 ;$ and viscosity of 5233,3 cP. The addition of red pomegranate extract produces handbody lotion that meets SNI 16-4399-1996.

Keywords: carrageenan; cetyl alcohol; handbody lotion; red pomegranate; vitamin c

\section{PENDAHULUAN}

Kulit kering adalah masalah kulit yang biasanya terjadi pada kulit manusia terutama masyarakat yang tinggal di negara tropis seperti Indonesia. Kulit yang kering dapat menyebabkan terjadinya penurunan pertahanan tubuh terhadap infeksi dan radikal bebas. Radikal bebas dapat memberikan efek penuaan dini dan kerusakan pada kulit manusia. Kulit yang rusak disebabkan oleh paparan sinar ultraviolet (UV) yang memiliki efek oksidatif sehingga dapat menyebabkan peradangan pada kulit. Sinar UV bersifat sebagai sumber radikal bebas dapat dicegah dengan antioksidan (Nova, 2012). Antioksidan adalah senyawa yang dapat mencegah reaksi berantai dari radikal bebas sehingga dapat menghindari kerusakan oksidatif pada molekul target, seperti protein, lipid, dan DNA (Halliwell, 2007). Salah satu jenis antioksidan adalah vitamin C. Menurut Sirat dan Sukesi (2012) vitamin C merupakan salah satu bentuk senyawa antioksidan yang berfungsi sebagai pencegah proses oksidasi, penuaan, gangguan kardiovaskular, dan dapat meregenerasi sel. Vitamin C sebagai antioksidan dapat ditambahkan ke dalam sediaan 
kosmetik berupa handbody lotion. Handbody lotion merupakan sediaan kosmetik berbentuk suspensi zat padat dengan pensuspensi yang tepat atau dapat berupa emulsi minyak dalam air dengan surfaktan yang cocok untuk diaplikasikan pada kulit bagian tangan dan tubuh manusia (Mitsui, 1997).

Handbody lotion dibuat dengan emulsifying agent agar sistem emulsinya stabil. Pengemulsi sekaliguas pengental dan penstabil yang biasanya digunakan dalam handbody lotion adalah setil alkohol. Menurut Erungan et al. (2009) sifat fungsional dari setil alkohol dapat digantikan oleh karagenan. Karagenan termasuk ke dalam emulsifying agent alami hasil proses ekstraksi dari rumput laut yang berfungsi sebagai agen pengemulsi dalam handbody lotion (Ramasari et al., 2012). Selain sebagai pengemulsi, karagenan juga berfungsi sebagai bahan penstabil dan pengental (Angka \& Suhartono, 2000). Karagenan dapat digunakan sebagai bahan penstabil dan pengental dalam suatu sistem suspensi atau emulsi tanpa terjadinya pembentukan gel (Hidayat, 2006). Penelitian mengenai pembuatan handbody lotion dengan menggunakan pengemulsi, pengental, dan penstabil karagenan telah dilakukan oleh Erungan et al. (2009), Purwaningsih et al. (2014), Tumbelaka et al. (2019), dan (Hardjata et al., 2020). Berdasarkan keempat hasil penelitian tersebut menunjukkan bahwa karagenan dapat digunakan dalam handbody lotion sebagai bahan pengemulsi, pengental, dan penstabil. Formulasi dibuat dengan memvariasikan konsentrasi bahan pengemulsi, pengental, dan penstabil setil alkohol dan karagenan. Hal ini ditujukan untuk mencari formula handbody lotion dengan konsentrasi bahan pengemulsi, pengental, dan penstabil setil alkohol dan karagenan terbaik yang memenuhi SNI 16-4399-1996 pada parameter penampakan, $\mathrm{pH}$, dan viskositas.

Seiring dengan berkembangnya ilmu pengetahuan dan teknologi, perkembangan produk kosmetik juga mulai bergerak ke arah natural product karena adanya trend back to nature (Duraisamy et al., 2011). Hal ini menjadikan penggunaan bahan alami sebagai zat aktif dalam kosmetik saat ini banyak dilakukan untuk meningkatkan nilai tambahnya. Bahan alami yang dapat ditambahkan ke dalam kosmetik handbody lotion adalah bahan yang mengandung antioksidan. Penelitian mengenai penambahan bahan alami pada handbody lotion telah dilakukan oleh Purwaningsih et al. (2014), Rahmatullah et al. (2019), dan Salsabila et al. (2020). Hasil dari penelitianpenelitian tersebut menunjukkan bahwa penambahan bahan alami dapat meningkatkan aktivitas antioksidan handbody lotion. Salah satu bahan alami yang mengandung antioksidan adalah ekstrak delima merah. Kandungan antioksidan utama dalam buah delima adalah asam askorbat (vitamin C) dan golongan polifenol seperti flavonoid dan tannin (Suranto, 2011). Tujuan penelitian ini untuk menentukan konsentrasi terbaik dari setil alkohol dan karagenan serta penambahan ekstrak delima merah pada handbody lotion.

\section{METODOLOGI}

\section{Metode Penelitian}

Metode penelitian yang digunakan adalah metode penelitian eksperimental laboratorium dengan analisis data statistik One-Way ANOVA dan uji lanjutan Duncan serta analiss deskriptif. Penelitian ini memiliki masing-masing 3 perlakuan untuk pengemulsi, pengental, dan penstabil yang berbeda jenis (setil alkohol dan karagenan). Perlakuan handbody lotion dengan setil alkohol terdiri dari perlakuan $A$ (setil alkohol 0,5\%), perlakuan B (setil alkohol 0,7\%), dan perlakuan C (setil alkohol 1,0\%). Perlakuan handbody lotion dengan karagenan terdiri dari perlakuan D (karagenan 1\%), perlakuan $\mathrm{E}$ (karagenan $2,0 \%$ ), dan perlakuan $\mathrm{F}$ (karagenan 3,0\%). Perlakuan handbody lotion terbaik dari masing-masing jenis pengemulsi, pengental, dan penstabil kemudian ditambahkan ekstrak delima merah dengan konsentrasi sebesar $0,2 \%$ dan $2,5 \%$.

\section{Alat dan Bahan}

Bahan-bahan yang digunakan dalam penelitian ini adalah ekstrak delima merah yang memiliki kadar vitamin $\mathrm{C}$ optimum sebesar $35,91 \mathrm{mg} / 100 \mathrm{~g}$, asam stearat, akuades, gliserin, karagenan, metil paraben, parafin cair, pewangi (Oleum citri), propil paraben, setil alkohol, trietanolamin, dan indikator $\mathrm{pH}$ universal.

Alat-alat yang digunakan dalam penelitian ini adalah beaker glass, mortir dan stamper, spatula, timbangan digital, viskometer, dan waterbath.

\section{Prosedur Penelitian}

\section{Pembuatan Handbody Lotion}

Formula handbody lotion dengan setil alkohol dapat dilihat pada Tabel 1 dan formula handbody lotion dengan karagenan dapat dilihat pada Tabel 2, serta formula handbody lotion terbaik dengan penambahan ekstrak delima merah dapat dilihat pada Tabel 3.

Tabel 1. Formula Handbody Lotion dengan Setil Alkohol

\begin{tabular}{lccc}
\hline \multirow{2}{*}{ Bahan } & \multicolumn{3}{c}{ Perlakuan $(\mathrm{g})$} \\
\cline { 2 - 4 } & $\mathrm{A}$ & $\mathrm{B}$ & $\mathrm{C}$ \\
\hline Asam Stearat & 7,5 & 7,5 & 7,5 \\
Setil Alkohol & 1,5 & 2,1 & 3,0 \\
Trietanolamin & 3,0 & 3,0 & 3,0 \\
Gliserin & 15,0 & 15,0 & 15,0 \\
Parafin Cair & 21,0 & 21,0 & 21,0 \\
Metil Paraben & 0,3 & 0,3 & 0,3 \\
Propil Paraben & 0,1 & 0,1 & 0,1 \\
Pewangi (Oleum citri) & 1,5 & 1,5 & 1,5 \\
Akuades & 250,2 & 249,5 & 248,7 \\
\hline Keterangan: & \multicolumn{3}{c}{}
\end{tabular}

Keterangan:

$\mathrm{A}=$ Handbody lotion dengan setil alkohol 0,5\%

$\mathrm{B}=$ Handbody lotion dengan setil alkohol 0,7\%

$\mathrm{C}=$ Handbody lotion dengan setil alkohol 1,0\%

Tabel 2. Formula Handbody Lotion dengan Karagenan

\begin{tabular}{lccc}
\hline \multirow{2}{*}{ Bahan } & \multicolumn{3}{c}{ Perlakuan } \\
\cline { 2 - 4 } & $\mathrm{D}$ & $\mathrm{E}$ & $\mathrm{F}$ \\
\hline Asam Stearat & 7,5 & 7,5 & 7,5 \\
Setil Alkohol & - & - & - \\
Karagenan & 3,0 & 6,0 & 9,0 \\
Trietanolamin & 3,0 & 3,0 & 3,0 \\
Gliserin & 15,0 & 15,0 & 15,0 \\
Parafin Cair & 21,0 & 21,0 & 21,0 \\
Metil Paraben & 0,3 & 0,3 & 0,3 \\
Propil Paraben & 0,1 & 0,1 & 0,1 \\
Pewangi (Oleum citri) & 1,5 & 1,5 & 1,5 \\
Akuades & 248,7 & 245,7 & 242,7 \\
\hline
\end{tabular}

Keterangan:

$\mathrm{D}=$ Handbody lotion dengan karagenan 1,0\%

$\mathrm{E}=$ Handbody lotion dengan karagenan 2,0\%

$\mathrm{F}=$ Handbody lotion dengan karagenan 3,0\% 
Tabel 3. Formula Handbody Lotion Terbaik dengan Penambahan Esktrak Delima Merah

\begin{tabular}{lcc}
\hline \multicolumn{1}{c}{ Bahan } & Perlakuan 1 $(\mathrm{g})$ & Perlakuan 2 $(\mathrm{g})$ \\
\hline Ekstrak Delima & 0,5 & 7,5 \\
Merah & 7,5 & 7,5 \\
Asam Stearat & 3,0 & - \\
Setil Alkohol & - & 9,0 \\
Karagenan & 3,0 & 3,0 \\
Trietanolamin & 15,0 & 15,0 \\
Gliserin & 21,0 & 21,0 \\
Parafin Cair & 0,3 & 0,3 \\
Metil Paraben & 0,1 & 0,1 \\
Propil Paraben & 1,5 & 1,5 \\
Pewangi & 248,2 & 235,2 \\
(Oleum citri) & &
\end{tabular}

Keterangan:

Perlakuan 1 = Handbody lotion terbaik setil alkohol dengan penambahan ekstrak delima merah $0,2 \%$

Perlakuan 2 = Handbody lotion terbaik karagenan dengan penambahan ekstrak delima merah $2,5 \%$

Pembuatan handbody lotion dimulai dari menimbang bahan-bahan yang diperlukan, kemudian memanaskan bahan-bahan tersebut menggunakan beaker glass di atas waterbath pada suhu $70^{\circ} \mathrm{C}-75^{\circ} \mathrm{C}$ hingga melebur. Bahanbahan yang dipanaskan dibagi menjadi ke dalam dua jenis, yaitu fase minyak (asam stearat, setil alkohol, parafin cair, propil paraben) dan fase air (trietanolamin, gliserin, metil paraben, akuades $1 / 3$ bagian). Setelah kedua fase melebur, fase minyak dimasukkan ke dalam mortir kemudian diaduk dengan pengadukan cepat dan konstan hingga sediaan homogen. Fase air yang telah melebur kemudian ditambahkan sedikit demi sedikit ke dalam fase minyak yang sudah ada di dalam mortir sambil diaduk secara konstan hingga sediaan homogen. Setelah sediaan homogen, ekstrak delima merah ditambahkan sambil terus diaduk. Langkah selanjutnya adalah menambahkan sisa akuades $2 / 3$ bagian sedikit demi sedikit ke dalam sediaan sambil terus diaduk hingga homogen, lalu tambahkan pewangi (Oleum citri) hingga tercampur dengan sediaan, kemudian aduk sediaan secara konstan sampai homogen. Setelah sediaan homogen, handbody lotion dimasukkan ke dalam wadah (Safitri \& Jubaidah, 2019) (Slamet \& U, 2019).

\section{Perhitungan Rendemen}

Menimbang massa awal bahan-bahan yang digunakan untuk membuat handbody lotion, kemudian menimbang massa akhir handbody lotion yang dihasilkan. Setelah itu, menghitung rendemen handbody lotion dengan menggunakan rumus sebagai berikut.

Rendemen $=\frac{\text { Massa akhir bahan }}{\text { Massa awal bahan }} \times 100 \%$

\section{Uji pH}

Uji pH handbody lotion dilakukan dengan cara sediaan digoreskan pada $\mathrm{pH}$ indikator ( $\mathrm{pH}$ universal), kemudian dilihat $\mathrm{pH}$ handbody lotion dari perubahan warna pada $\mathrm{pH}$ indikator (Slamet \& U, 2019).

\section{Uji Viskositas}

Viskositas handbody lotion diuji menggunakan seperangkat alat viskometer Brookfield. Sampel handbody lotion sebanyak kurang lebih 100 gram kemudian diuji dengan menggunakan spindel nomor 4 dan kecepatan 60 rpm. Viskositas dihitung dengan menggunakan rumus sebagai berikut.

Viskositas $=$ Dial reading $\times$ faktor

\section{Uji Penampakan}

Uji penampakan dilakukan dengan cara meletakkan sampel di atas cawan petri kemudian dilihat homogenitasnya (Tumbelaka et al., 2019).

\section{HASIL DAN PEMBAHASAN}

\section{Pembuatan Handbody Lotion}

Pembuatan handbody lotion dilakukan dengan menggunakan pengemulsi, pengental, dan penstabil setil alkohol dan karagenan secara terpisah. Alat gelas dan wadah disterilkan terlebih dahulu dengan pemanasan untuk menghindari terjadinya kontaminasi mikroba pada handbody lotion. Hal pertama yang dilakukan dalam membuat handbody lotion adalah dengan mencampurkan bahan-bahan sesuai dengan fasenya, yaitu fase air dan fase minyak pada suhu $70^{\circ} \mathrm{C}-75^{\circ} \mathrm{C}$ di atas waterbath melebur. Fase air pada perlakuan A, B, dan C menggunakan pengemulsi, pengental, dan penstabil setil alkohol, sedangkan pada perlakuan $D, E$, dan $F$ menggunakan karagenan. Fase minyak yang sudah melebur kemudian diaduk secara konstan lalu ditambahkan sedikit demi sedikit fase air sambil sediaan terus diaduk hingga homogen. Penambahan fase air sedikit demi sedikit dimaksudkan agar sediaan tidak menggumpal karena pencampuran kedua fase tersebut sedang melakukan proses emulsifikasi. Efektivitas proses emulsifikasi ditentukan oleh efisiensi pembentukan dan stabilisasi dari gumpalan yang terbentuk antara air dan minyak (Tumbelaka et al., 2019).

Tujuan penambahan emulsifying agent adalah untuk menurunkan tegangan permukaan antara fase minyak dan fase air dimana penurunan tegangan ini akan menyebabkan emulsifying agent membentuk lapisan yang mengelili fase minyak sheingga butiran minyak terdispersi ke dalam air. Setil alkohol dan asam stearat berfungsi sebagai thicking agent atau agen pengental yang dapat menjaga stabilitas emulsi dengan cara mengentalkan fase air. Penambahan trietanolamin (TEA) yang memiliki $\mathrm{pH}$ basa bertujuan untuk menurunkan $\mathrm{pH}$ asam yang dihasilkan asam stearat. Sifat basa TEA dapat menstabilkan $\mathrm{pH}$ asam dari asam stearat sehingga tidak dapat menyebabkan iritasi pada kulit. Gliserin bersifat higroskopis yang berfungsi untuk mencegah terjadinya penguapan air dari handbody lotion sehingga mencegah terjadinya kekentalan berlebih dan viskositas tidak semakin besar. Karagenan berperan sebagai bahan pengental sehingga penggunaan karagenan dalam handbody lotion berpengaruh terhadap penampakannya (Tumbelaka et al., 2019). Karagenan merupakan salah satu polimer alami yang bersifat hidrokoloid larut dalam air sehingga digunakan sebagai pengental dalam sediaan handbody lotion. Parafin cair bersifat sebagai emolien (Rowe et al., 2009) yang dapat mencegah dehidrasi pada kulit dan dapat memberikan efek lembab sebagai moisturizer karena dapat meningkatkan kandungan air. Metil paraben dan propil paraben berfungsi sebagai pengawet untuk mencegah terjadinya pertumbuhan jamur. Mikroba dalam handbody Iotion tidak diinginkan karena dapat menyebabkan emulsi rusak dan tidak stabil (Tumbelaka et al., 2019). Pewangi ditambahkan agar handbody lotion yang dihasilkan memiliki aroma tertentu sesuai yang diinginkan. Konsentrasi 
pewangi yang ditambahkan pada sediaan dalam jumlah yang sedikit agar tidak terjadi iritasi pada kulit (Rieger, 2000).

\section{Rendemen Handbody Lotion}

Tabel 4 menunjukkan rendemen pembuatan handbody lotion dengan setil alkohol dan Tabel 5 menunjukkan rendemen pembuatan handbody lotion dengan karagenan.

Tabel 4. Rendemen Handbody Lotion dengan Setil Alkohol

\begin{tabular}{cc}
\hline Perlakuan & Rendemen $(\%)$ \\
\hline A & $92,4 \pm 0,3^{\mathrm{a}}$ \\
B & $91,4 \pm 0,8^{\mathrm{a}}$ \\
C & $92,8 \pm 0,7^{\mathrm{a}}$ \\
\hline
\end{tabular}

$\bar{a}$ superscript dengan huruf berbeda menunjukkan perlakuan berbeda nyata

Tabel 5. Rendemen Handbody Lotion dengan Karagenan

\begin{tabular}{cc}
\hline Perlakuan & Rendemen (\%) \\
\hline D & $91,4 \pm 1,3^{\mathrm{a}}$ \\
E & $92,2 \pm 1,4^{\mathrm{a}}$ \\
F & $92,5 \pm 1,4^{\mathrm{a}}$ \\
\hline
\end{tabular}

${ }^{a}$ superscript dengan huruf berbeda menunjukkan perlakuan berbeda nyata

Hasil uji statistik menunjukkan bahwa nilai signifikansi rendemen handbody lotion dengan setil alkohol adalah sebesar 0,239 dan rendemen handbody lotion dengan setil alkohol adalah sebesar 0,733 yang berarti kedua nilai tersebut lebih besar dibandingkan dengan taraf signifikansi $0,05(\alpha=5 \%)$. Dapat disimpulkan bahwa perlakuan variasi konsentrasi setil alkohol dan karagenan dalam handbody lotion tidak memberikan pengaruh yang signifikan terhadap rendemen handbody lotion. Berdasarkan perhitungan rendemen yang didapatkan, diketahui bahwa semua perlakuan mengalami penyusutan berat sehingga persentase rendemen handbody lotion tidak $100 \%$. Persentse rendemen yang didapatkan berada pada rentang $91,4 \%-92,8 \%$, dimana hasil akhir berat handbody lotion menjadi sebesar 276,9 gram-278,5 gram. Hal tersebut dapat disebabkan oleh hilangnya massa bahan-bahan handbody lotion ketika dicampurkan, dimana pencampuran menggunakan beaker glass sehingga ada bahan yang tertinggal, terutama bahan yang memiliki kekentalan lebih tinggi dari akuades seperti gliserin, TEA, dan parafin cair. $\mathrm{Hal}$ lain yang menyebabkan rendemen handbody lotion berkurang adalah pada proses pemanasan terjadi penguapan terutama pada akuades. Selain itu, proses pengadukan yang manual menggunakan tangan di dalam mortir dapat menyebabkan handbody lotion ketika diaduk tumpah atau meluber.

\section{Uji pH}

Uji pH dilakukan untuk mengetahui tingkat keasaman dari handbody lotion yang dihasilkan. Pengukuran $\mathrm{pH}$ dilakukan dengan menggunakan $\mathrm{pH}$ indikator universal. Hasil pengukuran $\mathrm{pH}$ pada handbody lotion dengan setil alkohol dapat dilihat pada Tabel 6 dan hasil pengukuran $\mathrm{pH}$ pada handbody lotion dengan karagenan dapat dilihat pada Tabel 7.

Hasil uji statistik menunjukkan bahwa nilai signifikansi $\mathrm{pH}$ handbody lotion dengan setil alkohol adalah sebesar 1,000 dan rendemen handbody lotion dengan setil alkohol adalah sebesar 0,385 yang berarti kedua nilai tersebut lebih besar dibandingkan dengan taraf signifikansi $0,05(\alpha=5 \%)$. Dapat disimpulkan bahwa perlakuan variasi konsentrasi setil alkohol dan karagenan dalam handbody lotion tidak memberikan pengaruh yang signifikan terhadap $\mathrm{pH}$ handbody lotion. Tingkat keasaman handbody lotion perlu diuji untuk mengetahui keamanan dari $\mathrm{pH}$ handbody lotion pada saat digunakan agar tidak mengiritasi kulit. Sediaan topikal yang memiliki $\mathrm{pH}$ terlalu asam akan menyebabkan iritasi pada kulit, sedangkan jika $\mathrm{pH}$ terlalu basa akan menyebabkan kulit menjadi kering dan bersisik (Tranggono \& Latifah, 2007). Berdasarkan data yang didapatkan, semua perlakuan memiliki $\mathrm{pH} 8,0$ kecuali perlakuan 5 yang memiliki pH 7,0. Menurut Tumbelaka et al. (2019) penggunaan setil alkohol pada handbody lotion menyebabkan $\mathrm{pH}$ menjadi lebih tinggi dibandingkan dengan menggunakan karagenan. Hasil pengujian $\mathrm{pH}$ yang diperoleh berada pada rentang 7,0-8,0, dimana hasil tersebut masih termasuk ke dalam syarat mutu SNI 164399-1996 dimana syarat $\mathrm{pH}$ pelembab adalah 4,5-8,0.

Tabel 6. pH Handbody Lotion dengan Setil Alkohol

\begin{tabular}{cc}
\hline Perlakuan & $\mathrm{pH}$ \\
\hline A & $8,0 \pm 0,5^{\mathrm{a}}$ \\
B & $8,0 \pm 0,5^{\mathrm{a}}$ \\
C & $8,0 \pm 0,5^{\mathrm{a}}$ \\
\hline
\end{tabular}

$\bar{a}$ superscript dengan huruf berbeda menunjukkan perlakuan berbeda nyata

Tabel 7. pH Handbody Lotion dengan Karagenan

\begin{tabular}{cc}
\hline Perlakuan & $\mathrm{pH}$ \\
\hline D & $8,0 \pm 0,5^{\mathrm{a}}$ \\
E & $8,0 \pm 0,5^{\mathrm{a}}$ \\
F & $7,0 \pm 0,5^{\mathrm{a}}$ \\
\hline
\end{tabular}

$\overline{{ }^{a} \text { superscript dengan huruf berbeda menunjukkan perlakuan }}$ berbeda nyata

\section{Uji Viskositas}

Uji viskositas perlu dilakukan untuk mengetahui kekentalan handbody lotion yang dihasilkan. Viskositas merupakan tahanan alir suatu sediaan yang berperan penting dalam kestabilan emulsi yang dihasilkan (Masadi et al., 2018). Pengujian dilakukan dengan menggunakan viskometer Brookfield. Hasil uji viskositas handbody lotion dengan setil alkohol dapat dilihat pada Tabel 8 dan hasil uji viskositas handbody lotion dengan karagenan dapat dilihat pada Tabel 9.

Tabel 8. Viskositas Handbody Lotion dengan Setil Alkohol

\begin{tabular}{cc}
\hline Perlakuan & Viskositas $(\mathrm{cP})$ \\
\hline A & $3750,0 \pm 0,0^{\mathrm{a}}$ \\
B & $4200,0 \pm 70,7^{\mathrm{b}}$ \\
C & $4950,0 \pm 70,7^{\mathrm{c}}$ \\
\hline
\end{tabular}

$\overline{a, b, c}$ superscript dengan huruf berbeda menunjukkan perlakuan berbeda nyata

Tabel 9. Viskositas Handbody Lotion dengan Karagenan

\begin{tabular}{cc}
\hline Perlakuan & Viskositas (cP) \\
\hline D & $3925,0 \pm 35,4^{\mathrm{a}}$ \\
E & $4975,0 \pm 35,4^{\mathrm{b}}$ \\
F & $9262,5 \pm 88,4^{\mathrm{c}}$ \\
\hline
\end{tabular}

$\bar{a}$ superscript dengan huruf berbeda menunjukkan perlakuan berbeda nyata

Hasil uji statistik menunjukkan bahwa nilai signifikansi viskositas handbody lotion dengan setil alkohol adalah sebesar 0,001 dan rendemen handbody lotion dengan setil 
alkohol adalah sebesar 0,000 yang berarti kedua nilai tersebut lebih kecil dibandingkan dengan taraf signifikansi $0,05(\alpha=5 \%)$. Dapat disimpulkan bahwa perlakuan variasi konsentrasi setil alkohol dan karagenan dalam handbody lotion memberikan pengaruh yang signifikan terhadap viskositas handbody lotion. Berdasarkan hasil pengujian viskositas, didapatkan nilai viskositas handbody lotion menggunakan setil alkohol dan karagenan berkisar antara 3925,0 cP-9262,0 cP. Semua perlakuan handbody lotion memenuhi standar SNI 16-4399-1996 yang memiliki syarat viskositas sebesar 2000,0-50000,0 cP. Penggunaan berbagai konsentrasi setil alkohol dan karagenan pada masing-masing basis handbody lotion memberikan pengaruh yang signifikan terhadap perubahan viskositas. Perlakuan D memiliki konsentrasi karagenan yang paling kecil, sehingga viskositas yang dihasilkan juga paling kecil. Semakin tinggi konsentrasi setil alkohol, viskositas sediaan semakin besar, begitu pun dengan karagenan. Hasil ini sesuai dengan penelitian yang dilakukan oleh Erungan et al. (2009) dan Purwaningsih et al. (2014) yang menyatakan bahwa konsentrasi karagenan berpengaruh terhadap viskositas handbody lotion dimana semakin besar konsentrasi karagenan yang ditambahkan, maka viskositas handbody lotion semakin meningkat.

\section{Uji Penampakan}

Uji penampakan atau homogenitas dilakukan untuk mengetahui tercampur atau tidaknya sediaan dan melihat kestabilan emulsi handbody lotion yang dihasilkan. Hasil pengujian penampakan dapat dilihat pada Tabel 10.

Suatu emulsi dikatakan homogen jika tidak terlihat adanya pemisahan antara komponen penyusun emulsi tersebut (Erungan et al., 2009). Sediaan yang homogen akan menghasilkan kualitas handbody lotion yang baik karena menunjukkan bahan obat terdispersi dalam bahan dasar secara merata, sehingga dalam setiap bagian sediaan mengandung jumlah obat yang sama (Ulaen et al., 2012). Menurut Rieger (1994) homogenitas emulsi dipengaruhi oleh teknik atau cara pencampuran yang dilakukan serta alat yang digunakan pada proses pembuatan emulsi. Berdasarkan hasil pengujian penampakan, semua perlakuan homogen karena tidak adanya butiran kasar yang terlihat, yang menandakan bahwa handbody lotion yang dihasilkan tercampur secara merata dan memiliki stabilitas emulsi yang baik.

Tabel 10. Penampakan Handbody Lotion

\begin{tabular}{cc}
\hline Perlakuan & Penampakan \\
\hline A & Homogen \\
B & Homogen \\
C & Homogen \\
D & Homogen \\
E & Homogen \\
F & Homogen \\
\hline
\end{tabular}

\section{Pemilihan Handbody Lotion Terbaik}

Penelitian ini dilakukan untuk mengetahui handbody lotion terbaik untuk masing-masing bahan pengemulsi, pengental, dan penstabil yang digunakan, yaitu setil alkohol dan karagenan. Pemilihan handbody lotion terbaik dilihat dari parameter $\mathrm{pH}$, viskositas, dan penampakan. Ketiga parameter tersebut merupakan parameter yang terdapat di dalam SNI 16-4399-1996 dimana, syarat mutu handbodody lotion diantaranya adalah memiliki penampakan yang homogen, $\mathrm{pH}$ 4,5-8, dan viskositas 2000,0-50000,0 cP. Semua perlakuan handbody lotion yang dihasilkan memenuhi ketiga standar mutu tersebut. Berdasarkan hasil tersebut, maka pemilihan handbody lotion terbaik pada penelitian ini adalah dengan memilih konsentrasi setil alkohol dan karagenan pada handbody lotion yang menghasilkan viskositas paling tinggi. Hal ini disebabkan karena kestabilan emulsi handbody lotion dipengaruhi oleh tingkat viskositas emulsi tersebut. Menurut Schmitt (1996) semakin tinggi viskositas suatu bahan, maka bahan tersebut akan semakin stabil karena pergerakan partikel di dalam bahan cenderung sulit. Rekapitulasi hasil pengujian handbody lotion disajikan pada Tabel 11.

Tabel 11. Rekapitulasi Hasil Uji Parameter Handbody Lotion

\begin{tabular}{cccccccc}
\hline \multirow{2}{*}{ Parameter } & \multicolumn{9}{c}{ Perlakuan } & \multicolumn{2}{c}{ SNI 16- } \\
\cline { 2 - 7 } & $\mathrm{A}$ & $\mathrm{B}$ & $\mathrm{C}$ & $\mathrm{D}$ & $\mathrm{E}$ & $\mathrm{F}$ & $4399-1996$ \\
\hline Penampakan & Homogen & Homogen & Homogen & Homogen & Homogen & Homogen & Homogen \\
pH & 8,0 & 8,0 & 8,0 & 8,0 & 8,0 & 7,0 & $4,5-8,0$ \\
Viskositas (cP) & 3750,0 & 4200,0 & 4950,0 & 3925,0 & 4975,0 & 9262,5 & $2000,0-$ \\
& & & & &
\end{tabular}

Keterangan:

Warna kuning = Handbody lotion perlakuan terbaik dengan setil alkohol

Warna biru = Handbody lotion perlakuan terbaik dengan karagenan

Berdasarkan rekapitulasi hasil pengujian parameter penampakan, $\mathrm{pH}$, dan viskositas handbody lotion menunjukkan bahwa handbody lotion dengan konsentrasi pengemulsi, pengental, dan penstabil setil alkohol terbaik adalah pada perlakuan $\mathrm{C}$ dengan setil alkohol 1,0\% memiliki pH 8,0, viskositas $4950 \mathrm{cP}$ dan homogen. Sementara handbody lotion dengan konsentrasi pengemulsi, pengental, dan penstabil karagenan terbaik adalah pada perlakuan $\mathrm{F}$ dengan karagenan $3,0 \%$ memiliki $\mathrm{pH} 7,0$, viskositas $9262,5 \mathrm{cP}$ dan homogen. Perlakuan terbaik dari dua basis handbody lotion ini kemudian ditambahkan dengan ekstrak delima merah. Hasil pengujian parameter handbody lotion dengan penambahan ekstrak delima merah dapat dilihat pada Tabel 12.
Berdasarkan hasil pengujian, rendemen handbody lotion dengan penambahan ekstrak delima merah tidak berbeda jauh dengan rendemen handbody lotion tanpa ekstrak delima merah. Meskipun demikian, terjadi penyusutan berat pada handbody lotion yang dihasilkan. Penampakan dari handbody lotion juga tidak mengalami perubahan, dan sama-sama memiliki penampakan yang homogen. $\mathrm{pH}$ handbody lotion setelah ditambahkan ekstrak delima merah mengalami penurunan. Hal ini dapat disebabkan oleh sifat dari ekstrak delima merah yang asam karena mengandung asam askorbat. Hasil pengujian viskositas pada masingmasing handbody lotion mengalami penurunan dari viskositas awal basis handbody lotion setelah ditambahkan ekstrak delima merah. Hal ini dikarenakan penambahan ekstrak pada formula handbody lotion sehingga dapat menyebabkan viskositas menjadi berkurang. Menurut 
Rahmatullah et al. (2019) semakin tinggi konsentrasi ekstrak yang ditambahkan, maka sediaan lotion akan semakin encer. Dapat disimpulkan bahwa hasil pengujian parameter penampakan, $\mathrm{pH}$, dan viskositas handbody lotion perlakuan 1 dan 2 memenuhi syarat mutu SNI 163499-1996. Hal ini menandakan bahwa ekstrak delima merah dapat ditambahkan sebagai bahan aktif alami dalam formula handbody lotion.

Tabel 12. Hasil Uji Parameter pada Handbody Lotion dengan Penambahan Ekstrak Delima Merah

\begin{tabular}{ccc}
\hline Parameter & Perlakuan 1 & Perlakuan 2 \\
\hline Rendemen (\%) & 92,5 & 92,5 \\
Penampakan & Homogen & Homogen \\
pH & 7,0 & 7,0 \\
Viskositas & 4550,0 & 5233,3 \\
\hline
\end{tabular}

Keterangan:

Perlakuan 1 = Handbody lotion setil alkohol 1,0\% dengan ekstrak delima merah $0,2 \%$

Perlakuan $2=$ Handbody lotion karagenan 3,0\% dengan ekstrak delima merah $2,5 \%$

\section{KESIMPULAN}

Kesimpulan yang dapat diambil dari penelitian ini adalah semua perlakuan handbody lotion memenuhi SNI 16-43991996 (penampakan, $\mathrm{pH}$, viskositas) dimana handbody lotion terbaik dibuat menggunakan setil alkohol 1,0\% (rendemen 92,8\%; homogen; $\mathrm{pH} 8,0$; viskositas 4950,0 cP) dan karagenan 3,0\% (rendemen 92,5\%; homogen; $\mathrm{pH} 8,0$; viskositas 9262,5 cP). Hal ini menunjukkan bahwa sifat fungsional setil alkohol dapat digantikan oleh karagenan, sehingga kedua bahan pengemulsi, pengental, dan penstabil ini dapat digunakan dalam formulasi handbody lotion. Handbody lotion dengan setil alkohol 1,0\% dan ekstrak delima merah $0,2 \%$ memiliki rendemen $92,5 \%$; penampakan yang homogen; $\mathrm{pH} 7$; dan viskositas 4550,0 cP. Handbody lotion dengan karagenan 3,0\% dan ekstrak delima merah 2,5\% memiliki rendemen 92,5\%; penampakan yang homogen; $\mathrm{pH} 7,0$; dan viskositas 5233,3 cP. Penambahan ekstrak delima merah menghasilkan handbody lotion yang memenuhi SNI 16-4399-1996, sehingga ekstrak delima merah dapat ditambahkan sebagai bahan aktif alami dalam formula handbody lotion.

\section{DAFTAR PUSTAKA}

Angka, S. L., \& Suhartono, M. T. (2000). Bioteknologi Hasil Laut. PKSPL-IPB.

Duraisamy, A., Balakrishnan, K. P., \& Itc, R. (2011). Bioprospecting and new cosmetic product development: A brief review on the current status. International Journal of Natural Products Research, 1(3), 26-37.

Erungan, A. C., Purwaningsih, S., \& Anita, S. B. (2009). Aplikasi Karaginan Dalam Pembuatan Skin Lotion. Jurnal Pengolahan Hasil Perikanan Indonesia, 12(2), 128-143. https://doi.org/10.17844/jphpi.v12i2.873

Halliwell, B. (2007). Biochemistry of Oxidative Stress. Bioschem Soc Trans., 35(5).

Hardjata, D. A., Romadhon, \& Rianingsih, L. (2020). Karakteristik Fisiko Kimia Skin Lotion Ekstrak Albumin Ikan Gabus (Channa striata). Jurnal IImu Dan
Teknologi Perikanan, 2(2), 31-41.

Hidayat, F. (2006). Pengaruh Kombinasi Karaginan dan Sodium Lauryl Sulfat Serta Penambahan Ekstrak Pemphis acidula Terhadap Karakteristik Sabun Mandi Cair. Institut Pertanian Bogor.

Masadi, Y. I., Lestari, T., \& Dewi, I. K. (2018). Identifikasi Kualitatif Senyawa Terpenoid Ekstrak N-Heksana Sediaan Losion Daun Jeruk Purut (Citrus hystrix DC). Jurnal Kebidanan Dan Kesehatan Tradisional, 3(1), $1-56$.

Mitsui, T. (1997). New Cosmetic Science. Elsevier.

Nova, G. D. (2012). Formulasi Ekstrak Metanol Kulit Manggis (Garcinia mangostana L.) pada Uji Iritasi Primer. Universitas Sanata Dharma.

Purwaningsih, S., Salamah, E., \& Budiarti, T. (2014). Formulasi Skin Lotion dengan Penambahan Karagenan dan Antioksidan Alami dari Rhizophora Mucronata Lamk. Jurnal Akuatika Indonesia, 5(1), 55-62.

Rahmatullah, S., Permadi, Y. W., \& Utami, D. S. (2019). Formulasi dan Uji Aktivitas Antioksidan Sediaan Hand and Body Lotion Ekstrak Kulit Nanas (Ananas comosus (L.) Merr) dengan Metode DPPH. Jurnal Farmasi FIK UINAM, 7(1), Hal. 26-33.

Ramasari, E. L., Ma'ruf, W. F., \& Riyadi, P. H. R. (2012). Aplikasi Karagenan Sebagai Emulsifier Di Dalam Pembuatan Sosis Ikan Tenggiri (Scomberomorus Guttatus) pada Penyimpanan Suhu Ruang. Jurnal Perikanan, 1(2), 1-8.

Rieger, M. (1994). Theory and Pharmacy Practical Industry (S. Suyatmi (ed.); 2nd ed.). UI Press.

Rieger, M. (2000). Harry's Cosmeticology (8th Edition). Chemical Publishing Co. Inc.

Rowe, R. C., Sheskey, P. J., \& Quinn, M. E. (2009). Handbook of Pharmaceutical Excipients (6th Editio). The Pharmaceutical Press.

Safitri, C. I. N. H., \& Jubaidah, L. (2019). Formulasi dan Uji Mutu Fisik Sediaan Lotion Ekstrak Kulit Buah Jagung ( Zea mays L .). Jurnal Insan Farmasi Indonesia, 2(2), 175-184. https://doi.org/10.36387/jifi.v2i2.394

Salsabila, N., Indratmoko, S., \& O, A. T. N. L. (2020). Pengembangan Hand \& Body Lotion Nanopartikel Kitosan Dan Spirulina Sp Sebagai Antioksidan. Jurnal IImiah Jophus: Journal of Pharmacy UMUS, 2(01), $11-20$.

Schmitt, W. H. (1996). Chemistry and Technology of The Cosmetics and Toiletries Industry (2nd Editio). Blackie Academy and Profesional.

Sirat, D. W., \& Sukesi. (2012). Antioksidan dalam Bakso Rumput Laut Merah Eucheuma Cottonii. Jurnal Sains Dan Seni Pomits, 1(1), 1-4.

Slamet, S., \& U, W. (2019). Optimasi Formulasi Sediaan Handbody Lotion Ekstrak Daun Teh Hijau (Camellia sinensis Linn). Jurnal PENA, 33(1), 53-57.

Suranto, A. (2011). Terbukti Pome Tumpas Penyakit. Pustaka Bunda.

Tranggono, R., \& Latifah, F. (2007). Buku Pegangan IImu Pengetahuan Kosmetik. UI Press.

Tumbelaka, R. M. M. Y., Momuat, L. I., \& Wuntu, A. D. (2019). Pemanfaatan vco mengandung karotenoid tomat dan karagenan dalam pembuatan lotion. PHARMACON Jurnal IImiah Farmasi, 8(1), 94-105.

Ulaen, S. P. J., Banne, Y., \& Suatan, R. A. (2012). Pembuatan Salep Anti Jerawat dari Ekstrak Rimpang Temulawak (Curcuma xanthorrhiza Roxb.). Jurnal IImiah Farmasi, 3, 45-49. 